\title{
UCP1 is present in porcine adipose tissue and is responsive to postnatal leptin
}

\author{
Alison Mostyn', Linda Attig, Thibaut Larcher ${ }^{2}$, Samir Dou, Pascale Chavatte-Palmer ${ }^{3}$, \\ Monia Boukthir ${ }^{4}$, Arieh Gertler ${ }^{5}$, Jean Djiane ${ }^{6}$, Michael E Symonds ${ }^{7}$ and \\ Latifa Abdennebi-Najar
}

UP 2012.10.101 EGEAL, Institut Polytechnique LaSalle, Beauvais, France

${ }^{1}$ School of Veterinary Medicine and Science, University of Nottingham, Sutton Bonington Campus, LE12 5RD Nottingham, UK

${ }^{2}$ INRA UMR 703, Ecole Nationale Vétérinaire, Nantes, France

${ }^{3}$ INRA, UMR1198 BDR Biologie du Développement et Reproduction, Jouy-en-Josas, France

${ }^{4}$ Unité de Recherche 04UR08/03, Faculté de Médecine, Tunis, Tunisia

${ }^{5}$ The Hebrew University of Jerusalem, PO Box 12, Rehovot 76100, Israel

${ }^{6}$ Unité NOPA, INRA, Centre de recherche Jouy en Josas, Jouy-en-Josas, France

${ }^{7}$ Early Life Research Unit, Academic Child Health, School of Medicine, University Hospital,

The University of Nottingham, Nottingham NG7 2UH, UK

Correspondence should be addressed to L Abdennebi-Najar Email

latifa.najar@

lasalle-beauvais.fr

\begin{abstract}
Intrauterine growth restriction (IUGR) may be accompanied by inadequate thermoregulation, especially in piglets that are not considered to possess any brown adipose tissue (BAT) and are thus entirely dependent on shivering thermogenesis in order to maintain body temperature after birth. Leptin can stimulate heat production by promoting non-shivering thermogenesis in BAT, but whether this response occurs in piglets is unknown. Newborn female piglets that were characterised as showing IUGR (mean birth weight of approximately $0.98 \mathrm{~kg}$ ) were therefore administered injections of either saline or leptin once a day for the first 5 days of neonatal life. The dose of leptin was $0.5 \mathrm{mg} / \mathrm{kg}$, which is sufficient to increase plasma leptin by approximately tenfold and on the day of birth induced a rapid increase in body temperature to values similar to those of normal-sized 'control' piglets (mean birth weight of $\sim 1.47 \mathrm{~kg}$ ). Perirenal adipose tissue was then sampled from all offspring at 21 days of age and the presence of the BAT-specific uncoupling protein 1 (UCP1) was determined by immunohistochemistry and immunoblotting. UCP1 was clearly detectable in all samples analysed and its abundance was significantly reduced in the IUGR piglets that had received saline compared with controls, but was raised to the same amount as in controls in those IUGR females given leptin. There were no differences in gene expression between primary markers of brown and white adipose tissues between groups. In conclusion, piglets possess BAT that when stimulated exogenously by leptin can promote increased body temperature.
\end{abstract}
Key Words
- leptin
- UCP1
- porcine
- adipose tissue
- programming
- IUGR

\section{Introduction}

Brown adipose tissue (BAT) is essential for effective adaptation to cold exposure of the extra-uterine environment in precocial species such as sheep in which there is rapid activation of BAT around the time of birth (Clarke et al. 1997). In pigs, however, it has long been considered that BAT is not present (Trayhurn et al. 1989) and the newborn is http://joe.endocrinology-journals.org DOI: 10.1530/JOE-14-0155
() 2014 Society for Endocrinology Printed in Great Britain
Published by Bioscientifica Ltd
Journal of Endocrinology (2014) 223, M31-M38 
primarily dependent on shivering thermogenesis in muscle in order to prevent hypothermia at birth (Symonds \& Lomax 1992). This due to an open reading frame on the BAT-specific uncoupling protein 1 (UCP1) gene in the porcine species meaning that UCP1 is not expressed (Berg et al. 2006). However, it has more recently been suggested that BAT is present in young piglets because of the different morphological appearances of adipocytes within perirenal adipose tissue in 2-week-old females (Attig et al. 2008). However, this remains to be confirmed by direct measurements of UCP1. Moreover, our understanding of BAT has now been transformed as a consequence of the discovery of beige adipocytes that express UCP1 at approximately $10 \%$ of the amount observed in classical BAT (Nedergaard \& Cannon 2013, Wu et al. 2013), but whether comparable depots are be present in young pigs is not known.

The onset of non-shivering thermogenesis in BAT at birth is dependent on the rapid appearance of endocrine stimulatory factors, including leptin (Mostyn et al. 2001, Symonds 2013). When administered to female postnatal sheep, leptin improves thermoregulation in the newborn and then subsequently promotes the normal loss of UCP1 in the main fat depot (i.e. perirenal) over the first week of life (Mostyn et al. 2002). Daily administration of leptin to piglets showing intrauterine growth restriction (IUGR) between day 2 and day 10 after birth can partially rectify this adverse metabolic phenotype although its effects on adipose tissue appear to be confined to white adipocytes (Attig et al. 2008). The aim of this study was therefore to determine whether daily administration of leptin to piglets with IUGR from soon after birth up to 5 days of age not only improved thermoregulation, but also promoted the appearance of UCP1 within the perirenal depot by 3 weeks of age.

\section{Materials and methods}

\section{Animal management and in vivo leptin administration}

All procedures were approved by the Animal Ethics Committee (Comité Régional d'Ethique sur l'Expérimentation Animale, Ile-de-France Sud) and eight crossbred pigs $(1 / 4$ Large White $\times 1 / 4$ Duroc $\times 1 / 4$ Pietrain $\times 1 / 4$ Landrace) from our experimental farm (Lasalle Beauvais) were entered into the study. Within $24 \mathrm{~h}$ after birth (d0), all piglets were weighed and then only females were classified either as being of normal size (i.e. 'controls' mean weight $1.47 \pm 0.37 \mathrm{~kg}, n=26$ ) or having IUGR $(0.98 \pm 0.26 \mathrm{~kg}, n=48)$ based on a birth weight of $<1.0 \mathrm{~kg}$ (Guilloteau et al. 2010) and having a birth weight of $<30 \%$ of the mean (Blat et al. 2012). To avoid any confounding influence of sex and based on our previous studies, which showed significant effects of leptin on adipose tissue in females (Attig et al. 2008), only this sex of animal was entered into the study. Piglets were crossfostered to equalise litter sizes and minimise competition, and then piglets were allowed to remain with their foster mothers under infrared heating lamps $\left(32^{\circ} \mathrm{C}\right)$ until weaning at 21 days of age. From the day of birth until 5 days of age, one IUGR animal from each litter received a daily i.m. injection of saline (IUGR Sal, $n=24$ ) and another received $0.5 \mathrm{mg} / \mathrm{kg}$ porcine recombinant leptin (IUGR Lep, $n=24$ ) prepared as described previously (Attig et al. 2008, 2013). From 7 days of age, all piglets were allowed to access a starter commercial diet ad libitum that supplemented maternal milk feeding, according to the European recommendations for animal welfare in breeding (2001/91/CE, November 9, 2001). Body weight was recorded daily from 6 to 21 days of age. Buccal temperature was measured at birth using an electronic thermometer and then every day until 4 days of age, before each day's injection.

\section{Plasma and adipose tissue sampling}

At 21 days of age, blood samples were collected from all animals by venopuncture of the subclavian vein and then animals were killed with an i.p. injection of $90 \mathrm{mg} / \mathrm{kg}$ sodium thiopental (Nesdonal; Rhône-Mérieux, Nantes, France) and samples of perirenal adipose tissue taken and either snap frozen in liquid nitrogen to be stored at $-80^{\circ} \mathrm{C}$ or placed in $10 \%$ formal saline before fixing in $4 \%$ paraformaldehyde-phosphate buffer solution for histological analysis. The blood sample was centrifuged at $3000 \mathrm{~g}$ and the plasma was then stored at $-20^{\circ} \mathrm{C}$ until analysis.

\section{Laboratory analysis}

Histological assessment of perirenal adipose tissue Representative sections of adipose tissue were embedded in paraffin wax, transversally cut into $5-\mu \mathrm{m}$ thick sections as described previously (Attig et al. 2008) and then these were randomly selected to determine either the presence of UCP1 or adipocyte composition. Image analysis was performed using a digital camera (Nikon DXM 1200, Champigny, France) combined with image analysis software (Nikon Imaging Software). As many microscopic fields as necessary were randomly selected to observe at least 5682 adipocytes $(77 \pm 15$ adipocytes per sample). In addition to the morphological appearance of

Published by Bioscientifica Ltd. 
adipocytes, the area filled by each type was determined using Feret's minimum diameter. The coefficient of reproducibility (CR) values were 85.2 and $89.1 \%$, respectively, for BAT and white adipose tissues, and for white adipocyte number it was $96.9 \%$, with adipocyte density calculated in cells $/ \mu \mathrm{m}^{2}$. The mean adipocyte area was calculated from the number of cells within the same field.

Immunohistochemistry was undertaken on sections that were dewaxed using xylene, rehydrated through a series of ethanol baths of decreasing concentrations and then equilibrated in PBS. Endogenous peroxides were inactivated using $3 \% \mathrm{H}_{2} \mathrm{O}_{2}$. An avidin-biotin blocking kit (Vector Labs, Peterborough, UK) was used to block endogenous biotin, and 20\% normal goat serum was used to prevent non-specific binding. The slides were incubated with the UCP1 antibody (Schermer et al. 1996) diluted 1:10 000 in PBS-Tween overnight at $4{ }^{\circ} \mathrm{C}$. A biotinylated secondary antibody (BA-1000; Vector Labs) was diluted 1:400 in PBS-Tween and applied for $30 \mathrm{~min}$ at room temperature and then incubated for the same time period with Vectastain Elite ABC Reagent (Vector Labs), after which the antibody was visualised using a DAB substrate kit (SK-4100; Vector Labs). Each sample was counterstained with haematoxylin, rehydrated with ethanol and cleared with xylene before being mounted using DPX mounting. Liver and BAT prepared from 1-day-old sheep were used as negative and positive controls respectively; additionally, a sample of porcine subcutaneous adipose tissue from age-matched animals was included as a comparison.

Protein extraction and western blotting Mitochondria were prepared from $0.2 \mathrm{~g}$ frozen adipose tissue as described previously (Budge et al. 2000) and the protein content of each preparation determined (Bradford 1976). UCP1 content was measured, with $10 \mu \mathrm{g}$ mitochondrial protein run on $12 \%$ SDS gel, which was transferred onto a membrane (Imobilon, Millipore, Molsheim, France) and incubated for $1 \mathrm{~h}$ with the UCP1 antibody (1/10000 dilution; Schermer et al. 1996) followed by $1 \mathrm{~h}$ of incubation with a donkey anti-rabbit secondary antibody (1/2000 dilution; Abcam, Paris, France; ab16284). Specificity of detection was confirmed using non-immune rabbit serum (1/10 000 dilution). A range of molecular weight markers were included on all gels that were run in duplicate, together with a reference sample (ovine neonatal perirenal BAT) and negative control (ovine neonatal liver) was included on each.

Densitometric analysis was performed on each membrane following image detection using a Fujifilm LAS-1000 cooled CCD camera (Fuji Photo Film Co. Ltd, Tokyo, Japan).
All values are expressed in arbitrary densitometric units as a percentage of the reference sample. Abundance of cytochrome $c$ was determined using a commercial antibody (Santa Cruz Biotechnology, Los Angeles, CA, USA) at a dilution of 1:1000. The amount of UCP1 was normalised with the amount of cytochrome $c$ for each sample and the values are expressed in arbitrary units. In addition, conformation of equal loading of all samples was confirmed using Ponceau's (acid red 112) staining of all membranes.

\section{Gene expression}

Total RNA was extracted from approximately $0.5 \mathrm{~g}$ adipose tissue using the RNeasy Lipid Tissue Mini Kit (Qiagen), eluted in water and stored at $-80{ }^{\circ} \mathrm{C}$. The quality, purity and yield of this RNA were assessed by $1.5 \%$ agarose gel electrophoresis and using Nanodrop 6000 (Fisher Scientific, Nantes, France). A $1 \mu \mathrm{g}$ sample of total RNA was converted into cDNA using the Quantitect reverse transcription kit (Qiagen). Quantitative PCR was performed with $200 \mathrm{ng}$ cDNA, PCR master mix (FIREPol EvaGreen qPCR Supermix) and $100 \mu \mathrm{M}$ of each primer (Amplifix software) in a final volume of $50 \mu$ l. Thermal cycling conditions (RotorGenne 6000 ) were as follows: $12 \mathrm{~min}$ at $95^{\circ} \mathrm{C}, 30 \mathrm{~s}$ at $60^{\circ}$ and $30 \mathrm{~s}$ at $72^{\circ} \mathrm{C}$. Each reaction was performed in duplicate. Standard curves were constructed from serial tenfold dilutions using cDNA pooled equally from all animals. Peptidylprolyl isomerase (PPIA) was used as a reference gene to normalise the expression levels for the genes of interest. Quantification was performed using the calculation method of $\Delta \Delta \mathrm{Cq}$. The gene sequences were designed using the NCBI nucleotide databases based on sheep sequences (Pope et al. 2014) and the sequences used are listed in Table 1.

\section{Determination of plasma hormones and metabolite levels}

Blood samples were collected before killing on d21 into heparinised tubes. After centrifugation at $2500 \mathrm{~g}$, plasma was stored at $-20^{\circ} \mathrm{C}$ until analysis. Glucose, cholesterol and triglyceride concentrations were determined using commercial colorimetric-based kits, Glucose PAP Kit, Cholesterol Kit, Triglycerides Mono SL New Kit, ELITech Biotechnologies, Puteaux, France). Plasma thyroxine $\left(\mathrm{T}_{4}\right)$ and cortisol were determined by immunoenzymatic assays using the Cobas e411 Analyzer (Roche Diagnostics).

\section{Statistical analysis}

All results were subjected to ANOVA followed by post hoc Student's $t$-test or the Newman-Keuls test, as appropriate,

Published by Bioscientifica Ltd. 
Table 1 Specific sequence of forward and reverse oligonucleotide primers used for real-time PCR

\section{Names/accession number}

Receptor-interacting protein 140 (RIP140) XM_005670300.1

PR domain containing 16 (PRDM16) XM_005674522.1

Cyclooxygenase 2 (COX2) AF207824.1

Bone morphogenetic protein 7 (BMP7) NM_001105290.1

Uncoupling protein 1 (UCP1) AF060561

\section{Sequence}

F: 5'-ATCAGGCAGCGAGTGAAAGACTTG-3'

R: 5'-AGGAACGAGACCCATTGGACTTTG-3'

F: 5'-TCGGACAACCACGCACTTTTAGAC-3'

R: 5'-AGCTTGGTTCATCTCGCTGTTG-3'

F: 5'-TCCGACAGCCAAAGACACTCAAG-3'

R: 5'-TTATGTTCCCGCAGCCAGATTGTG-3'

F: $5^{\prime}$-CATGGTCATGAGCTTCGTCAAC-3'

R: 5'-GTCCTTGTAGATGCGGAATTCAGC-3'

F: 5'-CGTCATCCTATTGTGTGCTTG-3'

R: 5'-CATTGGTCTGTTCAATTCTTTTCC-5' or for qRT-PCR and histological analysis by the nonparametric Kruskal-Wallis test using the GraphPad Software. For the comparison of the proportion of pig mortality between groups, Fisher's exact test was carried out. For all analyses, the level of significance was set at $P<0.05$. All values are expressed as means \pm s.E.M. (except for body temperatures where the values are expressed as mean \pm s.e.).

\section{Results}

Piglet mortality, postnatal growth, thermoregulation and metabolic profiles at 3 weeks of age

The incidence of piglet mortality was higher in the IUGR group (control: 1 out of 26 vs IUGR Sal: 6 out of 24 , $P<0.05$ ), an effect that was reduced with leptin administration (IUGR Lep: 3 out of 24, NS). From birth to d5, growth rates were similar in the three groups (control: $53 \pm$ 3.6, IUGR Sal: $57 \pm 8.3$, IUGR Lep: $47 \pm 6.7 \%$ ). Weight gain then accelerated with leptin administration till the end of the study in comparison with IUGR piglets given only saline (Control: $274 \pm 9$ g, IUGR Sal: $263 \pm 11$ g, IUGR Lep: $325 \pm 190 \mathrm{~g}, P<0.01$ IUGR Sal vs Lep). Body temperature was lower with IUGR from the day of birth (Fig. 1), a difference abolished within $24 \mathrm{~h}$ of leptin administration, but, by day 4 of life, body temperature was similar in all groups. At 21 days of age, there were no differences in plasma concentrations of cholesterol or glucose between groups, but triglyceride concentration was significantly higher in the IUGR Sal group. Plasma $\mathrm{T}_{4}$ was reduced in IUGR Sal piglets, while there was a trend towards lower plasma cortisol concentrations in these offspring (Table 2).

\section{Adipose tissue composition}

A combination of morphometric and immunological analysis confirmed the presence of brown adipocytes in perirenal adipose tissue (Figs 2 and 3), whereas UCP1 was not present in the subcutaneous depot. These brown adipocytes showed two distinct morphologies, being either large and shapeless or with a more typical multilocular appearance. The mean density of white adipocytes was increased with IUGR, in which mean abundance of UCP1 as determined by immunoblotting was reduced (Fig. 3B), a response that was abolished by leptin administration. The bands for UCP1 and cytochrome c were in the same positions for the porcine and ovine samples, with the amount of UCP1 detected in a 21-day-old IUGR piglet that received leptin being similar to that observed in a 7-day-old sheep (Fig. 3C). There were no differences in expression of any genes examined (i.e. RIP140, UCP1, PRDM16, COX2 (PTGS2) and BMP7), and each was highly expressed in all samples, indicative of a beige adipose tissue depot (Table 3 ).

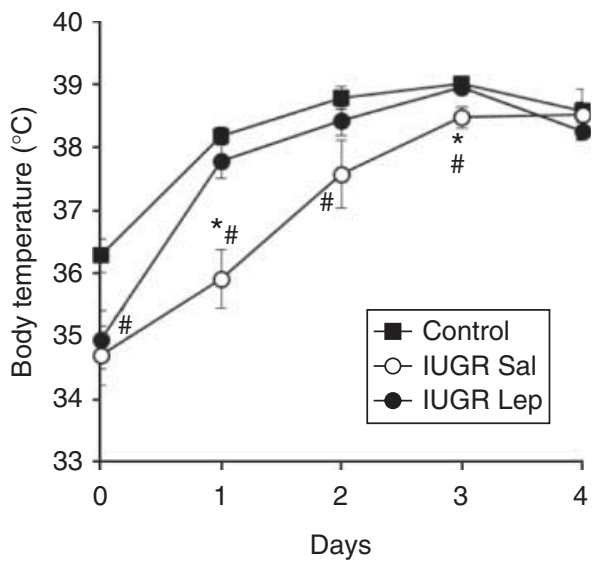

Figure 1

Effect of leptin administration once daily on body temperature in piglets with intrauterine growth restriction (IUGR). These were treated once a day with either saline ( $n=20$, represented by open circles) or leptin ( $n=17$, represented by filled circles) over the first 5 days of life and were also compared with untreated normal-sized piglets $(n=24$, represented by filled squares). Significant differences $(P<0.05)$ between IUGR Sal and Control (represented by \#) and IUGR lep (represented by *).

Published by Bioscientifica Ltd. 
Table 2 Mean plasma metabolites and hormones at 21 days of age in female normal-sized piglets $(n=11)$ and those with intrauterine growth restriction (IUGR) administered either saline $(n=10)$ or leptin $(n=14)$ over the first 5 days of life

\begin{tabular}{lcc}
\hline Plasma measurement & & Control \\
\cline { 1 - 1 } Thyroxine $(\mathrm{pmol} / \mathrm{l})$ & & $14 \pm 1$ \\
Cortisol $(\mathrm{nmol} / \mathrm{l})$ & & $173 \pm 19$ \\
Triglycerides $(\mathrm{mmol} / \mathrm{l})$ & & $1.4 \pm 0.2$ \\
Cholesterol $(\mathrm{mmol} / \mathrm{l})$ & & $3.65 \pm 0.46$ \\
\hline
\end{tabular}

\begin{tabular}{c}
\hline IUGR Sal \\
\hline $10 \pm 0.7$ \\
$131 \pm 15$ \\
$2.2 \pm 0.3$ \\
$3.60 \pm 0.32$ \\
\hline
\end{tabular}

\begin{tabular}{c}
\hline IUGR Lep \\
\hline $12 \pm 1.6$ \\
$130 \pm 18$ \\
$1.6 \pm 0.1$ \\
$3.67 \pm 0.40$ \\
\hline
\end{tabular}

\begin{tabular}{c}
\hline $\boldsymbol{P}$ value \\
\hline $0.016^{\mathrm{a}}$ \\
$\mathrm{NS}$ \\
$0.04^{\mathrm{a}}$ \\
$\mathrm{NS}$
\end{tabular}

NS, non-significant.

${ }^{a}$ For difference between IUGR Sal and control.

\section{Discussion}

We have shown for the first time, to our knowledge, that UCP1 is present in perirenal, but not subcutaneous, adipose tissue of the postnatal female piglet and its abundance has the potential to be increased by leptin administration. It has previously been accepted that BAT was absent in the piglet, as it could not be detected in any major fat depots of either neonatal, postnatal or juvenile pigs even following cold acclimation (Trayhurn et al. 1989). This earlier study used a different breed of pigs (i.e. Lacombe $\times$ Landrace with Large White) that were not cross-fostered to ensure equal litter size and adequate postnatal nutrition and also they did not undertake any histological analysis of the adipose tissue. Our results strongly indicate that perirenal adipose tissue in the piglet is a beige depot, rather than a classical brown depot, as it expresses genes that are either markers of brown or white adipose tissue (Pope et al. 2014). Furthermore, its histological appearance is indicative of a significant amount of white adipocytes between which comparatively small numbers of brown adipocytes are interspersed. These factors could all be important in explaining why previous studies have not been able to detect UCP1 in porcine adipose tissue, for example,
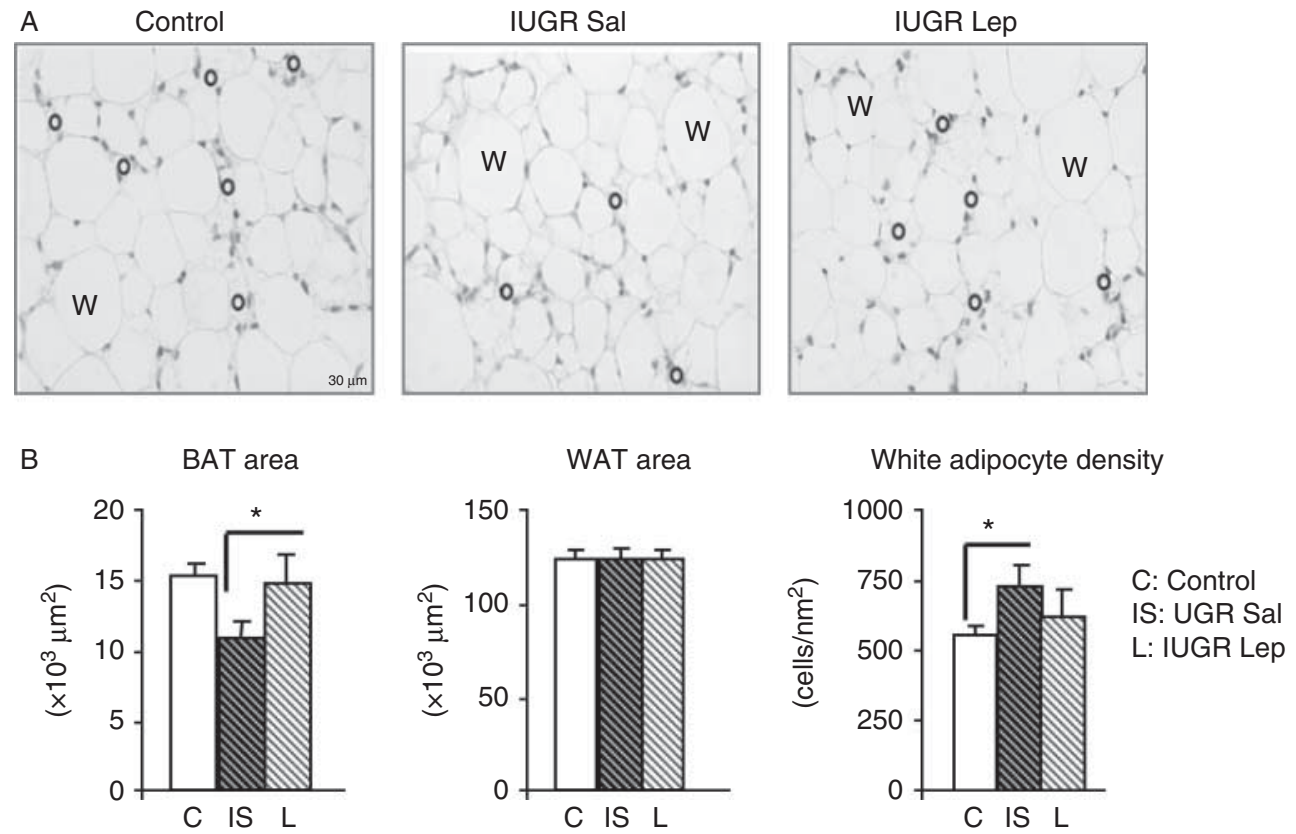

Figure 2

Effect of leptin administration once daily over the first 5 days of life to piglets showing intrauterine growth restriction (IUGR) on the morphological appearance of perirenal adipose tissue sampled at 21 days of age from females. (A) Histological analysis of control $(n=8)$ and IUGR piglets treated with either saline (IUGR Sal, $n=4$ ) or leptin (IUGR Lep, $n=4$ ).
$W$ and $O$ indicate white and brown adipocytes respectively. (B) The mean area of brown (BAT) and white adipose tissues (WAT) and white adipocyte density. The values are means with their standard errors and significant differences from either IS or $C$ indicated by $* P<0.05$. http://joe.endocrinology-journals.org DOI: 10.1530/JOE-14-0155
(C) 2014 Society for Endocrinology Printed in Great Britain
Published by Bioscientifica Ltd. 
A

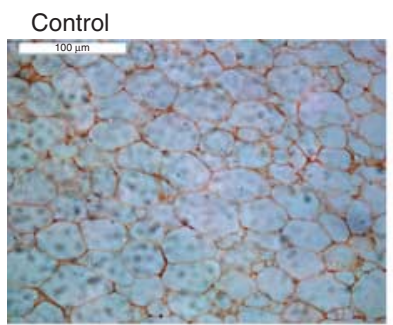

IUGR Sal

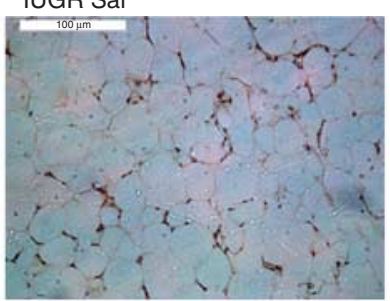

Negative control

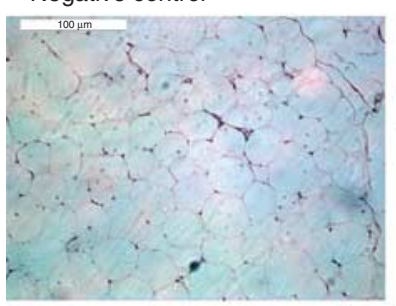

Control-subcutaneous

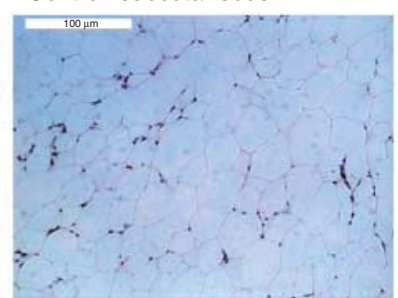

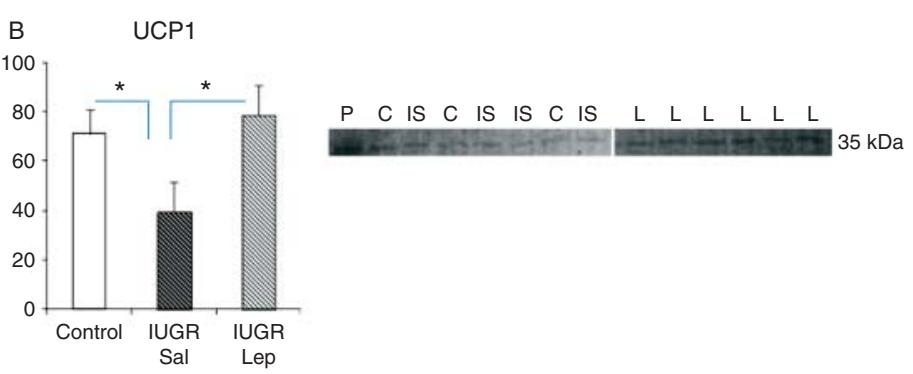

C
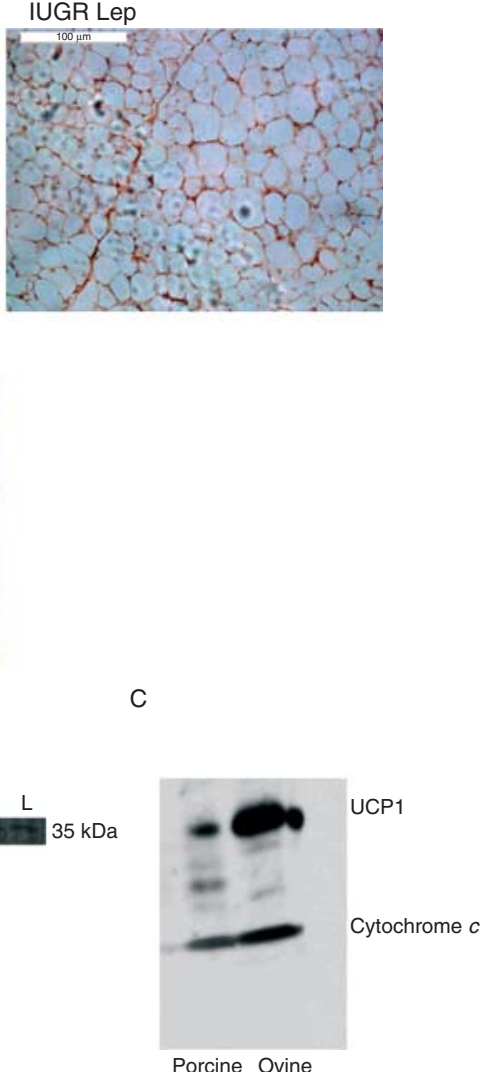

\section{Figure 3}

Effect of leptin administration once daily over the first 5 days of life to piglets showing intrauterine growth restriction (IUGR) on the presence of uncoupling protein 1 (UCP1) in perirenal adipose tissue sampled at 21 days of age from females. (A) Representative immunohistochemistry images from each group of piglets together with subcutaneous adipose tissue taken from an age-matched normal-sized animal and (B) Mean UCP1 abundance from 8 to 9 piglets per group as determined by western blot

immunoblotting procedures are not always sensitive enough to detect UCP1 within a beige depot (Jespersen et al. 2013). Additionally, differences in the offspring environment, including nutrition, can determine early adipose tissue development (Campbell \& Dunkin 1982, Darby et al. 1996).

The extent to which other adipose tissue depots similarly possess UCP1 in piglets remains to be determined, together with the extent to which UCP1possessing adipocytes actually disappear with age as opposed to new cells being recruited as is the case of the beigeing process described in adult rodents ( $\mathrm{Wu}$ et al. 2013). It is notable that the histological characteristics of the perirenal depot as measured at 21 days of age in this study were quite different from those described previously for a very similar cohort of piglets sampled at 14 days densitometry including representative blotting images ( $P$, positive control (from a 1-day-old sheep); C, control; IS, IUGR administered saline, L, IUGR administered leptin); (C) Example image for perirenal adipose tissue sampled from a 21-day-old piglet (porcine IUGR Lep) and 7-day-old sheep (Ovine). The values are means with their standard errors and significant differences between groups indicated by ${ }^{*} P<0.05$.

(Attig et al. 2008). In brief, the older piglets in this study possessed perirenal adipose tissue that had larger white adipocytes, but less BAT. Furthermore, we have shown that the abundance of UCP1 was reduced in IUGR piglets, whereas the density of white adipocytes was raised, an adaptation overcome by leptin administration over the first 5 days of postnatal life. At 21 days of age, IUGR piglets were also characterised as exhibiting lower plasma $\mathrm{T}_{4}$ and cortisol concentrations than controls, which are both important stimulatory factors that have been shown to promote BAT function in the perinatal sheep (Symonds et al. 2000, Mostyn et al. 2003). Our finding of increased plasma triglyceride concentrations in IUGR Sal piglets is in accordance with findings from low-birth-weight infants (Misra et al. 1984). It is possible that this reflects more efficient fat metabolism through non-shivering

Published by Bioscientifica Ltd. 
Table 3 Mean gene expression of markers of brown, beige and white adipose tissues as measured in perirenal adipose tissue sampled at 21 days of age from female normal-sized piglets $(n=11)$ and those with intrauterine growth restriction (IUGR) administered either saline $(n=10)$ or leptin $(n=14)$ over the first 5 days of life. The values for controls were set at 1 and they are means with their standard errors. There were no significant differences between groups

\begin{tabular}{|c|c|c|c|}
\hline Genes & Control & IUGR SaI & IUGR Lep \\
\hline $\begin{array}{l}\text { Receptor-interacting } \\
\text { protein }(R I P 140)\end{array}$ & 1 & $1.4 \pm 0.59$ & $0.86 \pm 0.62$ \\
\hline $\begin{array}{l}\text { Positive regulatory } \\
\text { domain-containing } \\
16 \text { (PRDM16) }\end{array}$ & 1 & $0.43 \pm 0.28$ & $0.64 \pm 0.53$ \\
\hline $\begin{array}{l}\text { Uncoupling protein } 1 \\
\text { (UCP1) }\end{array}$ & 1 & $0.85 \pm 0.57$ & $0.96 \pm 0.41$ \\
\hline $\begin{array}{l}\text { Cyclooxygenase } 2 \\
(\text { COX } 2)\end{array}$ & 1 & $0.52 \pm 0.27$ & $0.48 \pm 0.21$ \\
\hline $\begin{array}{l}\text { Bone morphogenetic } \\
\text { protein } 7 \text { (BMP7) }\end{array}$ & 1 & $0.92 \pm 0.57$ & $0.67 \pm 0.49$ \\
\hline
\end{tabular}

thermogenesis in BAT in the Control and IUGR Lep groups as indicated by raised body temperatures at 1 day of age and greater UCP1 abundance. There are potential long-term adverse health consequences for increased neonatal plasma triglycerides (Skilton 2008). Future studies can now be considered in young piglets to establish whether administration of these hormones can also promote UCP1. This could either be a direct response or by promoting the conversion of $\mathrm{T}_{4}$ to triiodothyronine by the enzyme $5^{\prime}$-monodeiodinase within BAT (Hall et al. 2010).

The effect of leptin on perirenal adipose tissue in piglets appears to persist well after its administration had ceased and the magnitude of responses both acutely on body temperature and in the longer term on UCP1 were much greater than those observed previously in neonatal sheep that were normal sized and female (Mostyn et al. 2002). This could be because, in young sheep, the rate of loss of BAT and its subsequent replacement with white adipose tissue are possibly much more rapid when compared with pigs, due in part to the concomitant growth of wool, widening of the thermoneutral zone (Symonds 2013) and replacement of non-shivering with shivering thermogenesis as the dominant response to acute cold exposure (Symonds et al. 1989). It remains to be established whether UCP1 is switched on at birth in piglets, as is the case in both humans and sheep that are also both born with a mature hypothalamic-pituitary axis (Symonds 2013), and/or whether it experiences a period of postnatal maturation as observed in altricial thermoregulators such as rodents (Nedergaard et al. 1986).

In conclusion, UCP1 is clearly present in perirenal adipose tissue of postnatal pigs and is sensitive to endocrine manipulation. This therefore provides a novel model for examining adipose tissue development in early life that could enable both the prevention of hypothermia after birth and excess adiposity in later life.

\section{Declaration of interest}

The authors declare that there is no conflict of interest that could be perceived as prejudicing the impartiality of the research reported.

\section{Funding}

This study was funded by Institut Polytechnique LaSalle Beauvais. LaSalle is an educational institute 'Grande Ecole', which offers outstanding scientific education to the future engineers in Nutrition and Health, Agriculture and Geology. INRA is a National institute of research in Agriculture. The funders had no role in study design, data collection and analysis, decision to publish or preparation of the manuscript.

Author contribution statement

A Mostyn, L Attig, M E Symonds and L Abdennebi-Najar contributed equally to this work.

\section{Acknowledgements}

The authors thank Ghada El Mhiri, Mourad Saidi (UP-EGEAL LaSalle Beauvais, France) and Luiz Felippe Barella (Laboratory of Secretion Cell Biology, Department of Biotechnology, Genetics and Cell Biology, University of Maringá, Brasil) for their assistance and Thierry Aussenac (LaSalle Beauvais, France) for support.

\section{References}

Attig L, Djiane J, Gertler A, Rampin O, Larcher T, Boukthir S, Anton PM, Madec JY, Gourdou I \& Abdennebi-Najar L 2008 Study of hypothalamic leptin receptor expression in low-birth-weight piglets and effects of leptin supplementation on neonatal growth and development. American Journal of Physiology Endocrinology and Metabolism 295 E1117-E1125. (doi:10.1152/ajpendo.90542.2008)

Attig L, Brisard D, Larcher T, Mickiewicz M, Guilloteau P, Boukthir S, Niamba CN, Gertler A, Djiane J, Monniaux D et al. 2013 Postnatal leptin promotes organ maturation and development in IUGR piglets. PLoS ONE 8 e64616. (doi:10.1371/journal.pone.0064616)

Berg F, Gustafson U \& Andersson L 2006 The uncoupling protein 1 gene (UCP1) is disrupted in the pig lineage: a genetic explanation for poor thermoregulation in piglets. PLoS Genetics 2 e129. (doi:10.1371/ journal.pgen.0020129)

Blat S, Morise A, Sauret A, Louveau I, Mace K, Le Huerou-Luron I \& Seve B 2012 The protein level of isoenergetic formulae does not modulate postprandial insulin secretion in piglets and has no consequences on later glucose tolerance. British Journal of Nutrition 108 102-112. (doi:10.1017/S0007114511005253) http://joe.endocrinology-journals.org DOI: 10.1530/JOE-14-0155
C 2014 Society for Endocrinology Printed in Great Britain 
Bradford MM 1976 A rapid and sensitive method for the quantitation of microgram quantities of protein utilizing the principle of protein-dye binding. Analytical Biochemistry 72 248-254. (doi:10.1016/0003-2697 (76)90527-3)

Budge H, Bispham J, Dandrea J, Evans L, Heasman L, Ingleton P, Sullivan C, Wilson V, Stephenson T \& Symonds ME 2000 Effect of maternal nutrition on brown adipose tissue and prolactin receptor status in the fetal lamb. Pediatric Research 47 781-786. (doi:10.1203/00006450-200006000-00017)

Campbell RG \& Dunkin AC 1982 The effects of birth weight and level of feeding in early life on growth and development of muscle and adipose tissue in the young pig. Animal Production 35 185-192. (doi:10.1017/ S0003356100027343)

Clarke L, Heasman L, Firth K \& Symonds ME 1997 Influence of route of delivery and ambient temperature on thermoregulation in newborn lambs. American Journal of Physiology Regulatory, Integrative and Comparative Physiology 272 R1931-R1939.

Darby CJ, Clarke L, Lomax MA \& Symonds ME 1996 Brown adipose tissue and liver development during early postnatal life in hand-reared and ewe-reared lambs. Reproduction Fertility and Development 8 137-145. (doi:10.1071/RD9960137)

Guilloteau P, Zabielski R, Hammon HM \& Metges CC 2010 Nutritional programming of gastrointestinal tract development. Is the pig a good model for man? Nutrition Research Reviews 23 4-22. (doi:10.1017/ S0954422410000077)

Hall JA, Ribich S, Christoffolete MA, Simovic G, Correa-Medina M, Patti ME $\&$ Bianco AC 2010 Absence of thyroid hormone activation during development underlies a permanent defect in adaptive thermogenesis. Endocrinology 151 4573-4582. (doi:10.1210/en.2010-0511)

Jespersen NZ, Larsen TJ, Peijs L, Daugaard S, Homoe P, Loft A, de Jong J, Mathur N, Cannon B, Nedergaard J et al. 2013 A classical brown adipose tissue mRNA signature partly overlaps with brite in the supraclavicular region of adult humans. Cell Metabolism 17 798-805. (doi:10.1016/ j.cmet.2013.04.011)

Misra PK, Tiwari DK, Sharma B \& Kaul R 1984 Free fatty acids and triglycerides in normoglycemic low birth weight newborns in early neonatal period. Indian Journal of Pediatrics 51 637-641. (doi:10.1007/BF02776378)

Mostyn A, Keisler DH, Webb R, Stephenson T \& Symonds ME 2001 The role of leptin in the transition from fetus to neonate. Proceedings of the Nutrition Society 60 187-194. (doi:10.1079/PNS200086)

Mostyn A, Bispham J, Pearce S, Evens Y, Raver N, Keisler DH, Webb R, Stephenson T \& Symonds ME 2002 Differential effects of leptin on thermoregulation and uncoupling protein abundance in the neonatal lamb. FASEB Journal 16 1438-1440. (doi:10.1096/fj.02-0077fje)

Mostyn A, Pearce S, Budge H, Elmes M, Forhead AJ, Fowden AL, Stephenson T \& Symonds ME 2003 Influence of cortisol on adipose tissue development in the fetal sheep during late gestation. Journal of Endocrinology 176 23-30. (doi:10.1677/joe.0.1760023)

Nedergaard J \& Cannon B 2013 UCP1 mRNA does not produce heat. Biochemica et Biophysica Acta 1831 943-949. (doi:10.1016/j.bbalip. 2013.01.009)

Nedergaard J, Connolly E \& Cannon B 1986 Brown adipose tissue in the mammalian neonate. In Brown Adipose Tissue, pp 152-213. Eds P Trayhurn \& D Nicholls. London: Edward Arnold.

Pope M, Budge H \& Symonds ME 2014 The developmental transition of ovine adipose tissue through early life. Acta Physiologica 210 20-30. (doi:10.1111/apha.12053)

Schermer SJ, Bird JA, Lomax MA, Shepherd DA \& Symonds ME 1996 Effect of fetal thyroidectomy on brown adipose tissue and thermoregulation in newborn lambs. Reproduction Fertility and Development 8 995-1002. (doi:10.1071/RD9960995)

Skilton MR 2008 Intrauterine risk factors for precocious atherosclerosis. Pediatrics 121 570-574. (doi:10.1542/peds.2007-1801)

Symonds ME 2013 Brown adipose tissue growth and development. Scientifica 2013 305763. (doi:10.1155/2013/305763)

Symonds ME \& Lomax MA 1992 Maternal and environmental influences on thermoregulation in the neonate. Proceedings of the Nutrition Society 51 165-172. (doi:10.1079/PNS19920026)

Symonds ME, Andrews DC \& Johnson PJ 1989 The control of thermoregulation in the developing lamb during slow wave sleep. Journal of Developmental Physiology 11 289-298.

Symonds ME, Bird JA, Sullivan C, Wilson V, Clarke L \& Stephenson T 2000 Effect of delivery temperature on endocrine stimulation of thermoregulation in lambs born by cesarean section. Journal of Applied Physiology 88 47-53.

Trayhurn P, Temple NJ \& Van Aerde J 1989 Evidence from immunoblotting studies on uncoupling protein that brown adipose tissue is not present in the domestic pig. Canadian Journal of Physiology and Pharmacology $\mathbf{6 7}$ 1480-1485. (doi:10.1139/y89-239)

Wu J, Cohen P \& Spiegelman BM 2013 Adaptive thermogenesis in adipocytes: is beige the new brown? Genes and Development 27 234-250. (doi:10.1101/gad.211649.112)

Received in final form 4 August 2014

Accepted 12 August 2014

Accepted Preprint published online 13 August 2014
(C) 2014 Society for Endocrinology Printed in Great Britain
Published by Bioscientifica Ltd. 